\title{
Nanoscale $\mathrm{TiO}_{2}$ nanotubes as a basis for governing cell behaviors and application challenges
}

\author{
This article was published in the following Dove Press journal: \\ International Journal of Nanomedicine \\ 13 January 2017 \\ Number of times this article has been viewed
}

Min $\mathrm{Li}^{1}$

Ying Yang ${ }^{2}$

'Department of Oncology, Changsha Central Hospital, Changsha, People's Republic of China; ${ }^{2}$ Department of Orthopaedic Surgery, Shanghai Ninth People's Hospital, Shanghai Jiao Tong University, School of Medicine, Shanghai, People's Republic of China

Correspondence: Ying Yang

Department of Orthopaedic Surgery,

Shanghai Ninth People's Hospital,

Shanghai Jiao Tong University School of

Medicine, 639 Zhizaoju Road, Shanghai

2000II, People's Republic of China

Tel +86 2I2 327 I I 33

Fax +862163137020

Email leeny520@126.com

\section{Dear editor}

$\mathrm{TiO}_{2}$ nanotube arrays with well-ordered nanotubular structures and controllable dimensions have emerged as a favorable substrate for advanced cell culturing with regulable cell behavior and differentiation. ${ }^{1,2}$ Unfortunately, the biological effects of nanotubes with different surface features on various cell lines are still inconsistent and inconclusive. Therefore, we read with great interest the enlightening work from Tian et $\mathrm{al}^{3}$ published in the International Journal of Nanomedicine on investigating the effects and molecular mechanisms of $\mathrm{TiO}_{2}$ nanotubes with various topographies and structures on the biological behavior of cultured cells.

This study demonstrated that the nanotube diameter, rather than the crystalline structure of the coatings, was a major factor determining the biological behavior of the cultured cells. Based on the results provided by this study, it was found that the optimal diameter of the coated nanotubes for cell adhesion, proliferation and migration was $20 \mathrm{~nm}$, which was also the critical threshold that suppressed the cell apoptosis. Similarly, Park et al ${ }^{4}$ reported that the biological behaviors of cells on nanotube coatings indicated that nanotubes with a diameter of $15-30 \mathrm{~nm}$ served as ideal materials to promote cell adhesion, proliferation and differentiation. ${ }^{5}$ The topic of this study is of significance for future localized therapeutics of both cancer and bone-related disorders. We appreciate the methodology of the study; nevertheless, we believe that the observations performed by the authors and their conclusions deserve further comment.

Closer examination of the data raises some concerns regarding the paper as the major conclusions presented are not in agreement with several previous studies. Even though the cell lines used in those studies are different, diverse biological performances of the tested cells mediated by similar topographies and structures also need further discussion. Çalışkan et $\mathrm{al}^{6}$ explored the cytocompatibility of $\mathrm{TiO}_{2}$ nanotubes with various diameters $(\sim 30 \mathrm{~nm}, 60 \mathrm{~nm}$ and $90 \mathrm{~nm})$ using human osteosarcoma cell line (Saos-2). This study found that the initial cell adhesion and proliferation rate was the highest on the nanotubes with intermediate diameter $(60 \mathrm{~nm})$. In addition, Choi et al ${ }^{7}$ demonstrated that the surface crystallinity of carbon nanostructures should be regarded as an additional independent factor for the inhibition of cancer proliferation. They indicated that human glioma cells (U372MG) significantly exhibited apoptosis, necrosis and cytotoxicity on carbon nanostructures with high crystallinity. In addition to cancer cells, mesenchymal stem cells (MSCs) have also been extensively used to examine the biological effects of $\mathrm{TiO}_{2}$ nanotubes. Oh et a ${ }^{8}$ observed that small $(\sim 30 \mathrm{~nm}$ diameter) nanotubes promoted MSC adhesion without noticeable differentiation, whereas larger ( $70-100 \mathrm{~nm}$ diameter) nanotubes elicited a dramatic MSC elongation, 
inducing selective differentiation into osteoblast-like cells. This special phenomenon may be attributed to the fact that MSCs cultured on $<50 \mathrm{~nm} \mathrm{TiO}_{2}$ nanotubes can more easily attach to the relatively narrow surfaces deposited with high population of extracellular matrix (ECM) proteins, whereas MSCs cultured on $100 \mathrm{~nm} \mathrm{TiO}_{2}$ nanotubes would probably have to struggle to search for more wider areas to establish initial contact. Our attention was drawn to the inconsistent results obtained from those investigations, which were mainly focused on the different biological responses with regard to the diameter and crystallinity of nanotube coatings.

Moreover, $\mathrm{TiO}_{2}$ nanotube arrays were shown to possess a unique set of properties for local drug delivery (LDD) applications, including controllable nanotube dimensions, high surface area, tunable geometries and surface chemistry, high and versatile drug-loading capacity, ability to modulate drug release kinetics and so forth. Based on those outstanding characteristics, $\mathrm{TiO}_{2}$ nanotube arrays have been widely used for localized therapeutics in various medical fields, such as orthopedic implants and localized cancer therapy.,10 Nevertheless, some technical challenges must be addressed and further explored before this technology becomes feasible and reliable for actual clinical applications. One challenge is the poor biodegradability of $\mathrm{TiO}_{2}$ nanotubes as compared to polymer implants. Another important concern is the potential nanotoxicity of $\mathrm{TiO}_{2}$ nanotube-based implants, which could be caused by nanotube delamination or degradation after implantation and release of $\mathrm{TiO}_{2}$ debris into the host body; therefore, more in vivo preclinical studies are required in the future to translate this technology into clinical trial stage. Furthermore, it requires more fabrication advances in terms of improvement of $\mathrm{TiO}_{2}$ nanotube production, scalability and reliability before they start to be produced at industrial scale. Finally, current public opinion regarding the clinical application of $\mathrm{TiO}_{2}$ nanotubes is also an important challenge, as the public has serious reservations about the use of nanomaterials in medicine.
In conclusion, we wish to thank Tian et $\mathrm{al}^{3}$ for figuring out the critical threshold nanotube diameter $(20 \mathrm{~nm})$ that regulates the biological behaviors of the tested cells. However, it should be noted that certain other surface characteristics, such as nanotube length, roughness, surface energy and wettability, may also inevitably affect the biological behaviors of cells on the nanotubes, which deserve further investigation in future studies. In addition, it would be beneficial to compare the effects of $\mathrm{TiO}_{2}$ nanotubes on a number of different cell lines.

\section{Disclosure}

The authors report no conflicts of interest in this communication.

\section{References}

1. Popat KC, Leoni L, Grimes CA, Desai TA. Influence of engineered titania nanotubular surfaces on bone cells. Biomaterials. 2007;28(21): 3188-3197.

2. Gulati K, Ramakrishnan S, Aw MS, Atkins GJ, Findlay DM, Losic D. Biocompatible polymer coating of titania nanotube arrays for improved drug elution and osteoblast adhesion. Acta Biomater. 2012;8(1): 449-456.

3. Tian A, Qin X, Wu A, et al. Nanoscale TiO nanotubes govern the biological behavior of human glioma and osteosarcoma cells. Int J Nanomedicine. 2015;10:2423-2439.

4. Park J, Bauer S, Schlegel KA, et al. $\mathrm{TiO}_{2}$ nanotube surfaces: $15 \mathrm{~nm}-$ an optimal length scale of surface topography for cell adhesion and differentiation. Small. 2009;5:666-671.

5. Bauer S, Park J, Faltenbacher J, et al. Size selective behavior of mesenchymal stem cells on $\mathrm{ZrO}_{2}$ and $\mathrm{TiO}_{2}$ nanotube arrays. Integr Biol (Camb). 2009;1:525-532.

6. Çalışkan N, Bayram C, Erdal E, Karahaliloğlu Z, Denkbaş EB. Titania nanotubes with adjustable dimensions for drug reservoir sites and enhanced cell adhesion. Mater Sci Eng C Mater Biol Appl. 2014;35:100-105.

7. Choi J, Lee S, Wang W, et al. Arresting cancer proliferation by controlling the surface crystallinity of carbon materials without generating reactive oxygen species. Acta Biomater. 2012;8(9):3457-3467.

8. Oh S, Brammer KS, Li YS, et al. Stem cell fate dictated solely by altered nanotube dimension. Proc Natl Acad Sci U S A. 2009;106:2130-2135.

9. Yang Y, Ao HY, Yang SB, et al. In vivo evaluation of the anti-infection potential of gentamicin-loaded nanotubes on titania implants. Int J Nanomedicine. 2016;11:2223-2234.

10. Kaur G, Willsmore T, Gulati K, et al. Titanium wire implants with nanotube arrays: a study model for localized cancer treatment. Biomaterials. 2016;101:176-188.

Dove Medical Press encourages responsible, free and frank academic debate. The content of the International Journal of Nanomedicine 'letters to the editor' section does not necessarily represent the views of Dove Medical Press, its officers, agents, employees, related entities or the International Journal of Nanomedicine editors. While all reasonable steps have been taken to confirm the content of each letter, Dove Medical Press accepts no liability in respect of the content of any letter, nor is it responsible for the content and accuracy of any letter to the editor.

International Journal of Nanomedicine

Dovepress

\section{Publish your work in this journal}

The International Journal of Nanomedicine is an international, peerreviewed journal focusing on the application of nanotechnology in diagnostics, therapeutics, and drug delivery systems throughout the biomedical field. This journal is indexed on PubMed Central, MedLine, CAS, SciSearch $\AA$, Current Contents $\AA /$ Clinical Medicine,
Journal Citation Reports/Science Edition, EMBase, Scopus and the Elsevier Bibliographic databases. The manuscript management system is completely online and includes a very quick and fair peer-review system, which is all easy to use. Visit http://www.dovepress.com/ testimonials.php to read real quotes from published authors. 